\title{
BIOMEDICAL PUBLICATIONS PRODUCTIVITY OF ORAL AND DENTAL MEDICINE FROM LIBYA (PUBMED 2003-2013)
}

Rahma Ahmed

Independent researcher and practicing dentist, Tripoli, Libya

ARTICLE INFORMATION:

Article History:

Received: 18 March, 2018

Accepted in revised form: 20 July, 2018

Published:28 December 2018

Corresponding author:

Rahma Ahmed

E-mail: ra.om88@ymail.com

Keyword:

Biomedical publications, oral and dentistry,

heath care, biomedical research, Libya

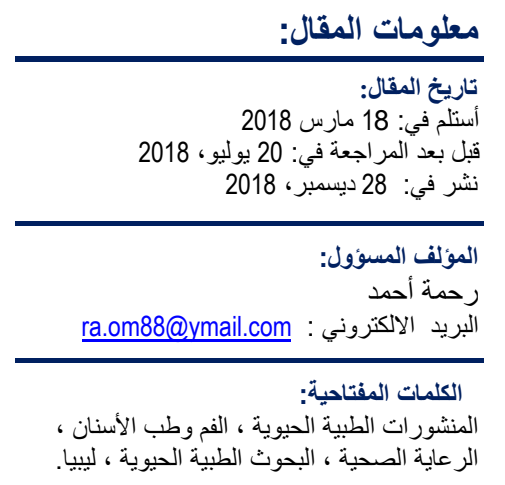

\begin{abstract}
:
The purpose of this short communication study was to investigation the trends of biomedical publications productivity of oral and dentistry field from Libya using the most popular biomedical search engine PubMed with focus on Libyan academic institutions. This search was performed on articles that were related to dentistry and oral medicine using the affiliation of Libya for the period 2003-2013. A total of 358 biomedical published articles were retrieved of which only 40 were related to oral and dentistry medicine. In conclusion, this investigation shows a very low productivity and weak distribution of biomedical research in oral and dentistry medicine productivity throughout Libya.
\end{abstract}

الملخص العربي

إنتاجية المنشورات الطبية لطب الفم والاسنان من ليبيا (2003-2013 ) رحمة أحمد

$$
\text { باحثة مستقلة وطبيبة أسنان، طر ابلس، ليبيا }
$$

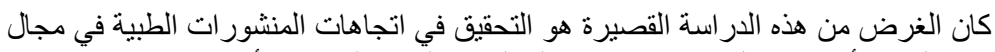

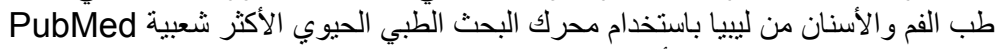

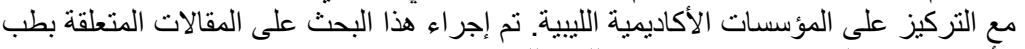

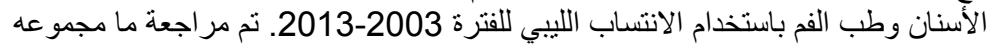

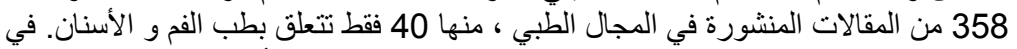

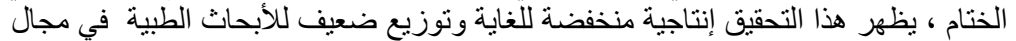
طب الفم والأسنان في جميع أنحاء ليبيا.

Copyright $\odot$ 2018. LDJ. This is an open access article distributed under the Creative Commons Attribution 3.0 License, which permits unrestricted use, distribution, and reproduction in any medium, provided the original work is properly cited.

Citation:Libyan Dent J 2018, 8: 201812004 -http://dx.doi.org/10.5542/LDJ.v8i0.201812004 


\section{INTRODUCTION}

Biomedical research productivity from under developed regions and low income countries are generally inadequate and their global contribution is limited. ${ }^{1,2}$ This is largely attributed to various financial and socioeconomical factors, regional instabilities, as well as undeveloped infrastructures. ${ }^{3}$ Libya is an Arab and North African country with fast natural resources but has been documented with a very low biomedical research productivity among Arab and African nations. ${ }^{4-7}$ Although many studies have investigated and analyzed the biomedical research productivity and trends from Libya, limited information is available on the oral and dentistry field or other professional medical disciplines. $^{8}$ Therefore the purpose of this brief study was to investigation the trends of biomedical publications productivity of oral and dentistry field from Libya using the most popular biomedical search engine PubMed with focus on Libyan academic institutions.

\section{MATERIALS AND METHODS}

The search was performed using the affiliation of Libya for the period 2003-2013. Only articles that were related to dentistry and oral medicine were selected and introduced into an excel data sheet for further descriptive analysis. Articles were further categorized and analyzed according to a number of criteria as following: publication year, affiliated Libyan cities, type of article, corresponding Libyan institution, and open access option of both article and the publishing journal.

\section{RESULTS}

A total of 358 biomedical published articles were retrieved of which only 40 were related to oral and dentistry medicine and further investigated. The trend which only started in 2007 was as following: $2007(n=1$; 2.5\%), 2008 ( $n=4 ; 10 \%), 2009(n=7 ; 17.5 \%), 2010$ $(n=5 ; 12.5 \%), 2011(n=2 ; 5 \%), 2012(n=6 ; 15 \%)$ and $2013(n=15 ; 37.5 \%)$ (Fig 1).

In total, 8 Libyan universities representing 5 cities were identified and respectively were; Al-Arab MedicalSciences University (Benghazi) ( $n=17$; 42.5\%), University of Tripoli (including former alfateh university) (Tripoli) ( $n=6 ; 15 \%)$, University of Benghazi (Benghazi) $(n=6 ; 15 \%), \quad$ University of Garyounis (Benghazi) ( $n=5 ; 12.5 \%)$, Al Jabal Al Gharbi University
(Al-Zawiya) $(\mathrm{n}=3 ; 7.5 \%)$, University of Sabha (Sabha) ( $n=3: 7.5 \%$ ) Libyan International Medical University (Benghazi) $(n=1 ; 2.5 \%)$, University of Al-Marghib (Al-Khoms) ( $n=1 ; 2.5 \%)$. Table1.

Further analysis revealed that $25 / 40$ articles (62.5\%) were research and original article and 9/40 $(22.5 \%)$ were case reports. Other types of articles such as review, journal article and short articles were only represented/each by $2.5 \%$ (i.e. 1 article). Also 30 articles (75\%) were affiliated to Libyan academic and health care institutions, 5 articles $(12.5 \%)$ were in open access journals and 18 articles $(45 \%)$ were an open access articles.

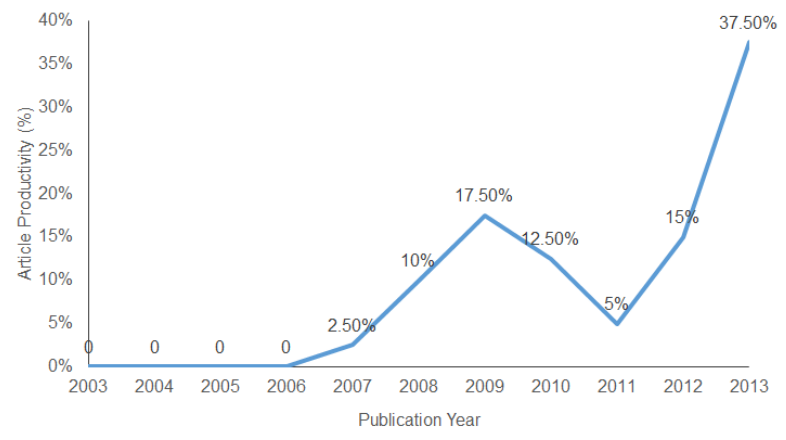

Fig1: Rate and frequency of biomedical publication of oral and dentistry medicine.

\section{DISCUSSION}

This short descriptive analysis show that Libyan biomedical publications affiliated to oral and dentistry science has only started in 2007 with one article and gradually increased to ward 2013 (Fig 1). This is a surprising results considering that the first biomedical publication from Libya was dated back in the 1952 and related to infectious disease. ${ }^{5,7}$ This data also show a dramatic decrease in 2011 which is probably attributed to the dramatic changes that affected the North African region during that year. Most of the analyzed published articles were affiliated to Benghazi universities which alone have published 29/40 articles (72.5\%) whereas other universities in the other cities have only contributed to less to $30 \%$ over 10 years period. 
Table1. Distribution of biomedical published article of oral and dentistry medicine.

\begin{tabular}{lll}
\hline University name & City & Number and proportion of produced articles \\
\hline Al-Arab Medical Sciences University & Benghazi & $17 ; 42.5 \%$ \\
University of Tripoli (including former alfateh university) & Tripoli & $6 ; 15 \%$ \\
University of Benghazi & Benghazi & $6 ; 15 \%$ \\
University of Garyounis & Benghazi & $5 ; 12.5 \%$ \\
Al Jabal Al Gharbi University & Al-Zawiya & $3 ; 7.5 \%$ \\
University of Sabha & Sabha & $3: 7.5 \%$ \\
Libyan International Medical University & Benghazi & $1 ; 2.5 \%$ \\
University of Al-Marghib & Al-Khoms & $1 ; 2.5 \%$ \\
\hline
\end{tabular}

Most of these papers were either original research articles or case reports and almost half of them were accessed articles but fewer in open access journals. A recent study by Peeran et al. have investigated the status of oral health care in Libya and investigated the related publication research productivity from Libya for the period November 2003- November 2013. ${ }^{8}$ This study has similarly concluded that Benghazi University (which currently include Al-Arab Medical Sciences and Garyounis University) was the highest publishing institutes, however they mentioned that thier study indicate that Tripoli University and Al Jabal Al Gharbi University scored the second highest productive rate.

\section{CONCLUSION}

In conclusion, this investigation shows a very low productivity and weak distribution of biomedical research productivity throughout the fast landscape of Libya. In Libya, there are 12 public and 5 private universities ${ }^{9}$ and this data show a very limited research and publications productivity of Libyan academic institutions from oral and dentistry schools.

\section{REFERENCES}

1. Langer A, Diaz-Olavarrieta C, Berdichevsky K, Villar J. Why is research from developing countries underrepresented in international health literature, and what can be done about it? Bull World Health Organ. 2004;82:802-803.

2. Uthman OA, Uthman MB. Geography of Africa biomedical publications: an analysis of 1996-2005 PubMed papers. Int J Health Geogr 2007;6:46.

3. Chu KM, Jayaraman S, Kyamanywa P, Ntakiyiruta G. Building research capacity in Africa: equity and global health collaborations. PLoS Med. 2014;11:e1001612.

4. Falagas ME, Zarkadoulia EA, Samonis G. Arab science in the golden age (750-1258 C.E.) and today. FASEB J. 2006;20:1581-1586.

5. Benamer HT, Bakoush O. Arab nations lagging behind other Middle Eastern countries in biomedical research: a comparative study. BMC Med Res Methodol. 2009;9:26.

6. Benamer HT, Bredan A, Bakoush O. A negative trend of biomedical research in Libya: a bibliometric study. Health Info Libr J. 2009;26:240-245.

7. Bakoush O, Al-Tubuly A, Ashammakhi N, Elkhammas E. PubMed Medical publications from Libya. Libyan J Med. 2007;2:125-128.

8. Peeran SW, Altaher OB, Peeran SA, Alsaid FM, Mugrabi $\mathrm{MH}$, Ahmed AM, et al. Oral health in Libya: addressing the future challenges. Libyan J Med. 2014;9:23564.

9. Higher education in Libya. National Tempus Office Libya, European commission. July 2012 Libya. http://eacea.ec.europa.eu/tempus/participating_countries/ overview/libya_overview_of_hes_final.pdf 